\title{
SURVEY OF MONILIFORMIN IN CORN CULTIVATED IN THE STATE OF SÃO PAULO AND IN CORN PRODUCTS COMMERCIALIZED IN THE CITY OF CAMPINAS, S.P.
}

\author{
Luís Antonio B. Leoni, Lucia M. Valente Soares*
}

Faculdade de Engenharia de Alimentos, Universidade Estadual de Campinas, Campinas, SP, Brasil.

Submitted: March 21, 2002; Returned to authors for corrections: August 01, 2002; Approved: January 07, 2003

\section{SHORT COMMUNICATION}

\begin{abstract}
Moniliformin, a toxin produced by Fusarium, was investigated in 22 samples of corn, 17 coming from districts of the state of São Paulo and 4 from experimental plots of the Campinas Institute of Agronomy, Brazil. The toxin was also investigated in 68 samples of corn products commercialized in Campinas, SP. Moniliformin was not detected in any sample.
\end{abstract}

Key words: mycotoxins, moniliformin, corn, Fusarium toxins

Moniliformin is a toxin produced mostly by Fusarium subglutinans (Wollenw. \& Reink.) Nelson, Toussoun \& Marassas $(22,26)$. It was first isolated and characterized by Cole et al. (7), who reported a $\mathrm{LD}_{50}$ of $4.0 \mathrm{mg} / \mathrm{kg}$ b.w. (p.o.) for 1 day old cockerels and described plant-growth regulating and phytotoxic effects of moniliformin on plants. A larger $\mathrm{DL}_{50}(5.4$ $\mathrm{mg} / \mathrm{kg}$ ) was found for day old cockerels by another group of workers (5). Kriek et al. (14) described the toxic symptoms of moniliformin in ducklings and rats as progressive muscular weakness, respiratory distress, cyanosis, coma and death. The oral $\mathrm{LD}_{50}$, reported by this group of researchers, was $3.68 \mathrm{mg} / \mathrm{kg}$ in 7 day old ducklings and 50.0 and $41.57 \mathrm{mg} / \mathrm{kg}$ in male and female rats, respectively.

Very low levels of moniliformin were observed to cause chromosomal aberration in liver cells in vitro (12). However, moniliformin showed negative results for the Ames test for mutagenicity $(12,33)$.

The presence of $50 \mathrm{mg}$ moniliformin/ $\mathrm{kg}$ in the feed of broiler chickens caused increased heart weight (19). Moniliformin and fumonisin $B_{1}$ in broiler chick feed has shown an additive effect in causing mortality (15), but a somewhat less than additive effect happens between deoxynivalenol and moniliformin inducing smaller feed intake and weight gain in broiler chicks (10).
Some experiments indicate moderate heat stability for this toxin. Up to 68 to $77 \%$ of the toxin was observed to remain when the potassium salt of moniliformin present in corn and wheat kernels was kept at room temperature during 6 days and when the grain was heated at $50^{\circ} \mathrm{C}$ during 2 hours. At higher temperatures, such as 100 to $150^{\circ} \mathrm{C}$, only $38 \%$ of the salt was present after 2 hours $(27,28)$.

Moniliformin producing Fusarium spp. have been reported in several parts of the world, such as, Argentina, Austria, Canada, Germany, Italy, Poland, New Zealand, Peru, South Africa, U.S. and parts of Asia and Africa $(2,3,4,8,9,17,21$, $24,26,29,30)$. Besides $F$. subglutinans, also strains of $F$. acuminatum, $F$. anthophilum $F$. avenaceum, F. concolor, $F$. denticulatum, F. equiseti, F. fujikuroi, F. fusarioides, F. moniliforme (now called $F$. verticilioides), $F$. oxysporum, $F$. proliferatum, F. ramigenum, F.sambucinum, F. semitectum, $F$. succisae, F. tricinctum, and F. thapsinum, were detected. The mentioned reports plus others found in the literature indicate that strains of $F$. moniliforme ( $F$. verticilioides) rarely produce the toxin $(1,11,16,22,25,28)$. Some authors even question its toxigenicity $(23,29,32)$.

Moniliformin have been found in corn in Canada, Germany, and New Zealand $(18,28,31)$, and in wheat in Austria and Poland

\footnotetext{
* Corresponding author. Mailing address: Faculdade de Engenharia de Alimentos, Universidade Estadual de Campinas. Caixa Postal 6121. 13081-970, Campinas, SP, Brasil. Fax: (+5519) 3289-2832. E-mail: valente@fea.unicamp.br
} 
$(2,20)$. Low levels of the toxin $(<0.25 \mathrm{mg} / \mathrm{kg})$ were determined in samples of corn products commercialized in the UK. The levels of toxin in corn samples from Africa, Asia and the European Union, varied from not detectable to $3.16 \mathrm{mg} / \mathrm{kg}$. Samples of Fusarium damaged oat, wheat and triticale were also found contaminated at levels from 0.05 to $399.3 \mathrm{mg} / \mathrm{kg}$ (30).

There have been no reports of surveys for the presence of moniliformin in Brazilian commodities. The present work aimed to investigate the presence of moniliformin in commercial corn planted in the state of São Paulo and corn products commercialized in the city of Campinas, SP.

Eighteen samples of freshly harvested corn were collected by personnel from the "Coordenadoria de Assitência Técnica de Pessoal de Nível Superior" (CATI) during transfer of corn to commercial silos located at the corn producing districts of Valentin Gentil, Bariri, Reginópolis, São Manuel, Votuporanga, Cafelândia, Olímpia, Cuna, Analândia, Casa Branca, Lutécia, Salto de Pirapora, São Sebastião da Grama, Santópolis do Aguapeí, Jales, Lorena (2 samplings), and Taubaté, all within the state of São Paulo, Brazil. The sampling was conducted by taking about $200 \mathrm{~g}$ at time intervals suitable to the amount of corn being transferred. The bulk sample was mixed and reduced by quartering and a $500 \mathrm{~g}$ sample was destined to moniliformin determination. All samples were stored in plastic bags at $-18^{\circ} \mathrm{C}$, and prior to analysis the grain was ground to 20 mesh.

Corn samples were also collected at four experimental plots of the Campinas Institute of Agronomy (IAC). They belonged to the cultivars "Cateto" (Jundiaí and Campinas), "Moroti" (Monte Alegre do Sul), "Taioba" (Campinas). A random block experimental design with three repetitions was used for each cultivar. The plots had 5 plants per $\mathrm{m}^{2}$ aligned in four 5 -meter rows with $0.9 \mathrm{~m}$ distance between rows. All ears were harvested in the two central rows of each plot. The kernels were shelled and combined. Samples were homogenized and reduced by quartering to $500 \mathrm{~g}$, stored in plastic bags at $-18^{\circ} \mathrm{C}$, and ground to 20 mesh prior to analysis.

Sixty-eight samples of corn products ( 25 corn flour, 24 popcorn, 19 corn for "canjica") were acquired at retail points in the city of Campinas, state of São Paulo, in amounts of at least $500 \mathrm{~g}$. The samples were stored in plastic bags at $-18^{\circ} \mathrm{C}$. Prior to analysis, the samples of "canjica" and popcorn were ground to 20 mesh.

Moniliformin, sodium salt, was obtained from the Council for Scientific and Industrial Research, South Africa. Concentrated solutions were prepared by weighing the salt to the nearest $0.001 \mathrm{mg}$ and dissolving it in a volumetric flask using methanol (Merck, Lichrosolv grade). Working standards were then prepared by dilution according to the need. Standard solutions were sonicated before use.

Five grams of sample were weighed and extracted with 50 $\mathrm{mL}$ methanol/water $(95+5)$ in a blender at medium speed during 5 minutes. The mixture was filtered through fluted filter paper.
An aliquot of $35 \mathrm{~mL}$ of the filtrate was collected and transferred to a separatory funnel. The sample extract was deffated twice with portions of $100 \mathrm{~mL}$ and $50 \mathrm{~mL}$ hexane. An aliquot of 35 $\mathrm{mL}$ was taken from the methanolic fraction and dried in a rotary evaporator at $40^{\circ} \mathrm{C}$. The dried residue was dissolved in $3 \mathrm{~mL}$ water and sonicated prior to the liquid chromatography step.

The extract was injected into a liquid chromatograph (model 9010, with integrator 4400, Varian) with the following conditions: injector loop, $20 \mu \mathrm{L}$; analytical column, Spherisorb ODS-1, 5 $\mu \mathrm{m}, 4.6 \mathrm{~mm} \times 250 \mathrm{~mm}$ (Altech); mobile phase, $42 \%$ of $350 \mathrm{mg}$ citrimide and $500 \mathrm{mg}$ zinc sulfate hepta hydrate/L plus $48 \%$ methanol, at a flow rate of $0.8 \mathrm{~mL} / \mathrm{min}$; ultraviolet diode array detector set at wavelength, $263 \mathrm{~nm}$ (Polichrom 9065, Varian).

The detection limit of the analytical method was $0.3 \mathrm{mg} / \mathrm{kg}$, determined by visually establishing the smallest peak that the analyst could comfortably see in the chromatogram. The calibration curve was linear up to $14 \mathrm{mg} / \mathrm{mL}$. The average recovery of the method was $84 \%$.

The samples of corn collected at silos right after harvest numbered 18. The corn storing silos were located at 17 districts of the state of São Paulo. The silos stored the commercial production of the area and were sampled during the process of filling the silos with the freshly harvested corn. The samples were all negative for moniliformin. The degree of infection of the samples by Fusarium spp was high, and varied between $16 \%$ and $80 \%$, as previously reported (6).

The four samples of corn harvested at experimental plots of the Campinas Institute of Agronomy (IAC) were also negative for moniliformin.

The samples of corn products commercialized in the city of Campinas, SP were also negative for moniliformin.

Results indicate that moniliformin is not a common contaminant in corn planted within the state. The samples of commercial corn products followed the same pattern. The origin of the corn used in these products is not known and it may have included imported corn. However, it should be noted that mycotoxin contamination can vary according to many factors. The genus Fusarium, although capable of growing on cereals during storage, it is mostly a field fungi. So, factors like weather conditions, Fusarium species, strains predominating during kernel growth and maturing stages, and types of corn hybrids being planted, may change the picture reported by the present work.

\section{ACKNOWLEDGEMENTS}

The authors thank the Fundação de Amparo à Pesquisa do Estado de São Paulo (FAPESP) for the financial support and the Coordenadoria de Aperfeiçoamento de Pessoal de Nível Superior (CAPES) for the graduate scholarship granted to the first author. 


\section{RESUMO}

\section{Investigação de moniliformina em milho cultivado no estado de São Paulo e em produtos de milho comercializados na cidade de Campinas, SP}

Moniliformina, uma toxina produzida por Fusarium, foi pesquisada em 22 amostras de milho, sendo 18 provenientes de 17 municípios do Estado de São Paulo, e 4 de estações experimentais do Instituto Agronômico de Campinas. A toxina foi investigada também em 68 amostras de produtos de milho comercializados em Campinas, SP. Moniliformina não foi detectada em nenhuma das amostras estudadas.

Palavras-chave: micotoxinas, moniliformina, milho, toxinas de Fusarium.

\section{REFERENCES}

1. Abbas, H.K.; Mirocha, C.J.; Comedla, T.; Versonder, R.F.; Golinski, P. Production of trichothecene and non-trichothecene mcytoxins by Fusarium species isolated from maize in Minnesota. Mycopathologia, 108: 55-58, 1989.

2. Adler, A.; Lew, H.; Broddacz, W.; Edinger, W.; Oberforster, M. Occurrence of moniliformin, deoxynivalenol, and zearalenone in durum wheat. Mycotoxin Res., 11: 9-15,1995.

3. Bosch, U.; Mirocha, C.J.; Abbas, H.K.; Menna, M. Tocicity and toxin production by Fusarium isolates from New Zealand. Mycopathologia, 108: 73-79, 1989.

4. Bottalico, A.; Visconti, A.; Solfrizzo, M. Production of moniliformin by Fusarium species, in Italy. Phytopathol. Mediterr., 21: 105-106, 1982.

5. Burmeister, H.R.; Ciegler, A.; Vesonder, R.F. Moniliformin, a metabolite of Fusarium moniliforme NRRL 6322: Purification and toxicity. Appl. Environ. Microbiol., 37: 11-13, 1979.

6. Castro, M.F.P.P.M.; Soares, L.M.V.; Furlani, R.P.Z. Mycoflora, aflatoxigenic species and mycotoxins in freshly harvested corn (Zea mays L.): A preliminary study. Rev. Microbiol., 26: 289-295, 1995.

7. Cole, R.J.; Kirksey, I.W.; Cuttler, H.G.; Doupnik, B.L.; Peckham, J.C. Toxin from Fusarium moniliforme: Effects on plants and animals. Science, 179: 1324-1326, 1973.

8. Desjardins, A.E.; Plattner, R.D.; Nelson, P.E. Production of fumonisin B1 and moniliformin by Gibberella fujikuroi from rice from various geographic areas. Appl. Environ. Microbiol., 63: 1838-1842,1997.

9. Farber, J.M.; Sanders, G.W.; Lawrence, G.A.; Scott, P.M. Production of moniliformin by Canadian isolates of Fusarium. Mycotopathologia, 101: 187-190, 1968.

10. Harvey, R.B.; Kubena, L.F.; Rottinghaus, G.E.; Turk, J.R.; Casper, H.H.; Buckley, S.A. Moniliformin from Fusarium fujikuroi culture material and deoxynivalenol from contaminated wheat incorporated into diets of broiler chicks. Avian Dis., 41: 957-963, 1997.

11. Jiménez, M.; Huerta, T.; Mateo, R. Mycotoxin production by Fusarium species isolated from bananas. Appl. Environ. Microbiol., 63: 364-369, 1997

12. Knasmüller, S.; Bresgen, N.; Kassie, F.; Mersch-Sundermann, V.; Gelderblom, W.; Zöhrer, E.; Eckl, P.M. Genotoxic effects of three Fusarium mycotoxins, fumonisin B1, moniliformin and vomitoxin in bacteria and in primary cultures of rat hepatocytes. Mutation Res., 39: 39-48, 1997.

13. Kononenko, G.P.; Soboleva, N.A.; Leonov, A.N. The intensity of moniliformin biosynthesis in Fusarium avenaceum and Fusarium moniliforme isolates. Appl. Biochem. Microbiol., 32: 304-307, 1996.
14. Kriek, N.P.J.; Marasas, W.F.O.; Steyn, P.S.; Van Rensburg, S.J.; Steyn, M. Toxicity of a moniliformin-producing strain of Fusarium moniliforme var subglutinans isolated from maize. Food Cosmet. Toxicol., 15: 57-587, 1977.

15. Kubena, L.F.; Edrington, T.S.; Harvey, R.B.; Buckley, S.A.; Phillips, T.D.; Rottinghaus, G.E.; Caspers, H.H. Individual and combined effects of fumonisin $\mathrm{B}_{1}$ present in Fusarium moniliforme culture material and T-2 toxin or deoxynivalenol in broiler chicks. Poult. Sci., 76: 1239-1247, 1997.

16. Latus- Zietkiewicz, D.; Chelkowski, J.; Formska, E.; Golinski, P.; Grabarkiewcz-Szczesna, J.; Kostecki, M.; Lew, M.; Perkowski, J.; Piasecki,M.; Wiewiorowska, M.; Szebiotko. Biosyntesis of gibberellic acid and mycotoxins by F. moniliforme Sheldon and other species of Liseola section. Natural Tox., 4: 228-233, 1996.

17. Lauren, D.R.; Agnew, M.P.; Smith, W.A.; Sayer, S.T. A survey of the natural occurrence of Fusarium mycotoxins in cereals grown in New Zealand in 1986-1989. Food Add. Contam. 8: 599-605, 1991

18. Lamprecht, S.C.; Marasas, W.F.O.; Thiel, P.G.; Schneider, D.J.; KnoxDavies, P.S. Incidence and toxigenicity of seedborne Fusarium species from Annual Medicago species in South Africa. Phytopathology, 76: 1040-1041, 1986.

19. Ledoux, D.R.; Bermúdez, A.J.; Rottinghaus, G.E.; Broomhead, J.; Bennett, G.A. Effects of feeding Fusarium fujikuroi culture material, containing known levels of moniliformin, in young broiler chicks. Poult. Sci., 74: 297-305, 1995.

20. Lew, H.; Chelkowski, J.; Wakulinski, W.; Edinger, W. Moniliformin in wheat and triticale grain. Mycotoxin Res., 9: 66-71, 1993.

21. Logrieco, A.; Moretti, A.; Altomare, C.; Bottalico, A.; Carbonell Torres, E. Occurrence and toxicity of Fusarium subglutinans from Peruvian maize. Mycopathologia, 122: 185-190, 1993.

22. Marasas, W.F.O.; Thiel, P.G.; Rabie, C.J.; Nelson, P.E.; Tousson, T.A. Moniliformin production in Fusarium section Liseola. Mycologia, 78: 242-247, 1986.

23. Mirocha, C.J.; Abbas, H.K.; Versonder, R.F. Absence of trichothecenes in toxigenic isolates of Fusarium moniliforme. Appl. Environ. Microbiol., 56: 520-525, 1990.

24. Peralta Sanhueza, C.E.; Gonzalez, H.H.L.; Resnik, S.L. Moniliformin production by Fusarium species isolated from Argentinian corn. Mycotoxin Res., 12: 2-6, 1996.

25. Rabie, C.J.; Lubben, A.; Louw, A.I.; Rathbone, E.B.; Steyn, P.S.; Vleggr, R. Moniliformin, a mycotoxin from Fusarium fusarioides. J. Agric. Food Chem., 26: 375-379, 1978.

26. Rabie, C.J.; Marasas, W.F.O.; Thiel, P.G.; Lübben, A.; Vleggaar, R. Moniliformin production and toxicity of different Fusarium species from Southern Africa. Appl. Environ. Microbiol., 43(3): 517 521,1982

27. Scott, P.M.; Lawrence, G.A.; Matula, T.I. Analysis of toxins of Fusarium moniliforme. In: Steyn, P.S.; Vleggaar, R. (eds.). Mycotoxins and Phycotoxins. Elsevier, Amsterdam, 1986, p. 305-316.

28. Scott, P.M.; Abbas, H.K.; Mirocha, C.J.; Lawrence, G.A., Weber, D. Formation of moniliformin by Fusarium sporotrichioides and Fusarium culmorum. Appl. Environ. Microbiol. 53: 196-197, 1987.

29. Schütt, F.; Nirenberg, H.I.; Deml, G. 1998. Moniliformin production in the genus Fusarium. Mycotoxin Res., 14(1): 35-40.

30. Sharman, M.; Gilbert, J.; Chelkowski, J. A survey of the occurrence of the mycotoxin moniliformin in cereal samples from sources worldwide. Food Add. Contam., 8: 459-466, 1991.

31. Thalman, A.; Matzenauer, S.; Gruber-Schley, S. Untersuchungen über das Vorkommen von Fusarientoxinen in Getreide. Berichte über Landwirtschaft, 63: 257-272, 1985.

32. Versonder, R.F. Moniliformin produced by cultures of Fusarium moniliforme var. subglutinans isolated from swine feed. Mycopathologia, 95: 149-153, 1986.

33. Wehner, F.C.; Marasas, W.F.O.; Thiel, P.G. Lack of mutagenicity to Salmonella typhimurium of some Fusarium mycotoxins. Appl. Environ. Microbiol., 35: 659-662, 1978. 